INTERNATIONAL JOURNAL OF MULTIDISCIPLINARY RESEARCH AND ANALYSis

ISSN(print): 2643-9840, ISSN(online): 2643-9875

Volume 04 Issue 11 November 2021

DOI: 10.47191/ijmra/v4-i11-21, Impact Factor: 6.072

Page No.- 1626-1627

\title{
The Portrait Genre in the Fine Arts if Uzbekistan Is Part of the Work of Abdulhaq Abdullayev
}

\author{
Adolat Khomidkhonova \\ Student, National Institute of Art and Design named after Kamoliddin Behzod
}

ABSTRACT: At a time when the development of Uzbek fine arts was at its peak, the "second wave" artists contributed to the formation of Uzbek national and local artists. Thus, L.Abdullayev, B.Hamdami, A.Abdullayev, Sh.Khasanova, M.Nabiyev, A.Siddiqi, Ch.Akhmarov and others began their creative paths (4, p. 294). The work of the artist A.Abdullayev, who marked the development of the Uzbek portrait genre, deserves special attention.

KEYWORDS: Moscow Art School, Pushkin Museum, Tretyakov Gallery, inner essence, experiences, mood and character.

\section{INTRODUCTION}

Dedicated to the creation of a contemporary image, the Honored Artist Abdulhaq Abdullayev is the first national painterportraitist in the fine arts of Uzbekistan (3, p. 7). His teacher P. Benkov played an important role in his involvement in painting and connecting his work with portraits. During his studies at the Samarkand University, as a result of his great work and research, he took part in the first exhibition of Uzbek artists in Moscow (1934). In Moscow, he visited the Tretyakov Gallery and the Pushkin Museum and admired Repin's paintings. This is where A.Abdullayev decided to try himself in the genre of portraiture (3, p. 8).

A.Abdullayev emphasizes realism in the creation of portraits. The first reason is that in 1940-1950, social realism prevailed in the fine arts, and young artists, on the one hand, mastered realism for their obligations, and on the other hand, A.Abdullayev studied at the Moscow Art School named after Surikov and was not completed due to the war, who has an academic background.

\section{THE MAIN FINDINGS AND RESULTS}

The artist created his first professional series of portraits in the early 1940s, depicting villagers. Paintings are usually created in one or two sessions because hardworking characters do not have time to stand for long periods of time. This situation required the author to have the ability to feel good about people and psychological knowledge (3, p. 8). A.Abdullayev skillfully revealed the inner essence, experiences, mood and character of the image.

Thus, with in-depth research and 5 years of work, Abdulhaq Abdullayev began to create intricate portraits. In a series of paintings by Uzbek intellectuals, the artist created the image of well-known contemporaries. Among them are portraits of actor Abror Khidoyatov, academician Qori Niyazov, film director Komil Yormatov, writer Uygun, people's artists S. Ishontorayeva and Mannon Uyghur.

In the late 40's A.Abdullayev created portraits of folk masters and famous cotton growers. For example, there are images of craftsmen such as Usto Shirin Murodov and Toshpolat Arslonkulov, as well as portraits of cotton grower Nazarali Niyazov in several variants.

The artist's desire to show the described psychology as vividly and clearly as possible can be seen in his efforts to create the image of Nazarali Niyazov. A.Abdullayev wanted to create the image of a cotton grower while working on the collective farm. However, the image was so multifaceted and profound that the young artist, who had just begun his career, did not dare to take it. Even then, A.Abdullayev, despite his advanced skills, failed to create a complete and expressive portrait in one go. The artist Nazarali Niyazov created five different versions of his portrait. With each new picture, the image became more complete, deeper and more realistic, the details of the environment became more expressive, and the composition became clearer and more convincing. 


\section{The Portrait Genre in the Fine Arts if Uzbekistan Is Part of the Work of Abdulhaq Abdullayev}

The best of these five portraits of Nazarali Niyazov is a 1949 version. It was as if a famous cotton grower was standing on the edge of a cotton field for a moment with a ketmon on his shoulder. His youthful, vigorous, and youthful stature is clearly reflected in the sky. His eyes are fixed on the field in a serious and glorious way. The image of a blackened face in the sun, a bright and upright figure, strong hands, as well as a self-confident cotton grower, the hero is a real hard worker, a master of his craft, enthusiastic and tireless. indicates that $(3$, p. 10). Abdulhak Abdullayev is a great portraitist, so it is important for him to reflect not only the appearance of the object, but also the human qualities, to show the inner world of the protagonist, to strive for the image to be realistic, to create works that have a strong impact on the audience.

\section{CONCLUSION}

Throughout his career, A.Abdullayev portrayed hundreds of other famous people, artists, intellectuals and just ordinary people, full of similar expression, bright character, color-saturated and fully revealing the interior of the object. reflected in the pictures of the transmitter. For the artist, man is the greatest and most perfect gift of nature, the source of endless inspiration, the true manifestation of beauty. This view of Abdulhaq Abdullayev is confirmed in his paintings.

\section{REFERENCES}

1) Abdullaev A. Thirst for the beautiful: Memories, articles, speeches. Tashkent: KKZHI, 1994. -p. 192.

2) 2 Akhmedova N. Painting of Central Asia of the 20th century: traditions, originality, dialogue. Tashkent: NIIII, 2004. -p. 224

3) Iras I. Artists of Soviet Uzbekistan. Tashkent: GIHL UzSSR, 1959. -p. 298.

4) Khakimov A. History of arts of Uzbekistan. Tashkent: “Info Capital Group”, 2018. -p. 416. 